\title{
DEVELOPMENT OF THE INDUSTRIAL COMPLEX OF KRYVORIZHIA: ECONOMIC BENEFITS, TECHNOGENIC CONSEQUENCES AND ENVIRONMENTAL PROBLEMS
}

\author{
*Mykola NAZARUK, Maksym OSTROUSHKO \\ Ivan Franko National University of Lviv, Ukraine \\ *mm.nazaruk@gmail.com
}

\begin{abstract}
The rapid economic development of Kryvyi Rih and large-scale geospatial changes in the territory are associated with the development of the iron ore basin and the development of the mining and industrial complex and ferrous metallurgy enterprises of the city. The study aims to highlight the positive economic factors of industrial development in the region and to study the whole complex of geospatial changes in the territory. The task of the research is also to understand the negative environmental consequences and ways to solve the problems of environmental pollution. As a result of studying historical sources and cartographic materials in the study it was possible to understand the patterns of spatial development of the city and the scale of geospatial changes in Kryvyi Rih. In the course of the work, objects of anthropogenic landscapes, water bodies and territories of industrial enterprises were studied and plotted on the city map. This made it possible to understand the peculiarities of the location, the scale of the transformation of the territory and man-made danger. The development of industry in addition to the clear economic benefits brought the city a number of environmental problems and man-made hazards such as: (1) concentration of potentially dangerous objects in the city (mines, quarries, dumps, sludge storages, waste cavities, etc.), which require annual discharge of excess return water; (2) formation of abysmal landscapes, which is associated with underground mining of iron ores and the displacement of adjacent blocks of native rocks; (3) the presence of waste from the extractive industry, which is presented in the form of dumps, sludge storages, heaps and landfills, forming zones of man-made desertification, the area of which by the end of the XX century. amounted to about $8 \%$ of the total territory of Ukraine; (4) emissions of pollutants into the atmosphere by the enterprises of the complex, which annually amount to more than 260 thousand tons (according to the Dnipropetrovsk regional council); (5) soil pollution as a result of industrial enterprises; (6) water pollution by heavy metals, which occurs due to discharges of insufficiently treated water by enterprises of the mining, metallurgical and metalworking industries directly into the rivers of the region.
\end{abstract}

Key words: man-made danger, mining industry, anthropogenic landscapes, quarries, stockpiles, karst landscapes, ecological condition.

DOI: https://doi.org/10.17721/2413-7154/2021.86.77-85

UDC: [913(477.64):502.131]:930.2

Received: October 23, 2021.

Revised: December 30, 2021.

Accepted: December 31, 2021.

\section{РОЗВИТОК ПРОМИСЛОВОГО КОМПЛЕКСУ КРИВОРІЖЖЯ: ЕКОНОМІЧНІ ПЕРЕВАГИ, ТЕХНОГЕННІ НАСЛІДКИ ТА ЕКОЛОГІЧНІ ПРОБЛЕМИ}

\author{
*Микола НАЗАРУК, Максим ОСТРОУШКО \\ Львівський національний університет імені Івана Франка, Україна \\ *mm.nazaruk@gmail.com
}

\begin{abstract}
Анотація: Стрімкий економічний розвиток Криворіжжя та масштабні геопросторові зміни території пов'язані із розробкою залізорудного басейну та розбудовою гірничо-видобувного промислового комплексу і підприємств чорної металургії міста. Дослідження ставить за мету висвітлити позитивні економічні чинники розвитку промисловості регіону та вивчити весь комплекс геопросторових змін території. Також завданням дослідження $\epsilon$ розуміння негативних екологічних наслідків та шляхів вирішення проблем забруднення навколишнього середовища. В результаті вивчення історичних джерел та картографічних матеріалів у дослідженні вдалося виявити закономірності просторового розвитку території міста та масштаби геопросторових змін Криворіжжя. В ході роботи були досліджені та нанесені на карту міста об'єкти антропогенних ландшафтів, водних об'єктів та території промислових підприємств. Це дало змогу осягнути особливості розміщення, масштаби перетворень території та техногенної небезпеки. Розвиток промисловості, окрім економічних вигод, приніс місту низку екологічнихпроблем та техногенних небезпек: (1) концентрація потенційно небезпечних об'єктів на території міста (шахти, кар'єри, відвали, шламосховища, відпрацьовані пустоти, тощо), які потребують щорічного скиду надлишків зворотних вод; (2) утворення провальних ландшафтів, що пов'язано з підземним видобутком залізних руд та зрушенням прилягаючих блоків корінних гірських порід; (3) наявність відходів видобувної промисловості, які представлені у вигляді відвалів, шламосховищ, териконів та звалищ, що формують зони техногенного опустелювання, площа яких до кінця XX ст. склала близько 8\% від загальної території України; (4) викиди забруднюючих речовин в атмосферне повітря підприємствами комплексу, які щорічно складають понад 260 тис т (за офіційними даними Дніпропетровської обласної ради); (5) забруднення грунтів в результаті діяльності промислових підприємств; (6) забруднення вод важкими металами, яке відбувається через скиди недостатньо очищеної води підприємствами гірничодобувної, металургійної та металообробної промисловості безпосередньо в річки регіону.
\end{abstract}

Ключові слова: техногенна небезпека, гірничодобувна промисловість, антропогенні ландшафти, кар'єри, відвали, провальні ландшафти, екологічний стан. 
Вступ. Початок видобутку залізної руди у промислових масштабах на Криворіжжі 140 років тому став поштовхом для стрімкого промислового розвитку регіону. В результаті лише за період 3 30-х по 70-ті роки XX століття Кривий Ріг із невеликого містечка перетворився у місто-промисловий гігант. Криворізький регіон зазнав швидкого економічного розвитку, але разом з тим промисловий комплекс докорінно змінив ландшафти та призвів до надзвичайно серйозних екологічних проблем та техногенних небезпек. Тому важливим є вивчення та дослідження геопросторових змін території, екологічних небезпек та пошук вирішення проблем.

Дане дослідження ставить за мету комплексно висвітлити позитивні економічні чинники розвитку промислового комплексу Криворіжжя та вивчити геопросторові зміни території як наслідки розвитку гірничо-промислового комплексу.

Завданням дослідження $є$ висвітлення техногенних і екологічних проблем, та вплив на навколишне середовище промислового комплексу в місті Кривий Ріг, пов'язаних зі стрімким розвитком гірничовидобувного та промислового комплексу регіону.

Теоретико-методологічні основи дослідження. В останне десятиліття зріс інтерес науковців до вивчення антропогенних змін території Криворіжжя та вивчення гірничопромислових ландшафтів. Так у статті В. Казакова «На шляху до повного вивчення гірничопромислових ландшафтів Кривбасу» представлена база даних вивченої просторовочасової структури гірничопромислових ландшафтів території міста і регіону. Дослідник визначив метою роботи обгрунтування схем оптимізації гірничопромислових ландшафтів та включення їх до регіональних екомереж, врахування їх структури в розробці генплану міста Кривого Рогу, для розвитку різноманітних напрямків індустріального туризму (Kazakov, 2000). Екологічним проблемам міста присвячено багато наукових досліджень, зокрема Е. Часова у статті «Екологічні проблеми Кривбасу - стан та перспективи» висвітлила реальний стан та гостроту екологічних небезпек промислового міста Кривий Ріг (Kazakov, 2000; Kazakov \& Herasymchuk 2008; Chasova \& Ivchuk, 2012). Антропогенні ландшафти Кривбасу були об'єктом дослідження М. Сметани та Т. Провоженко (Smetana \& Provozhenko, 2017).

\section{Методи дослідження та дані}

В процесі даного дослідження була використана низка методів, які допомогли дослідити геопросторові зміни та наслідки антропогенного впливу на довкілля в регіоні. Так дослідження історичних картографічних матеріалів та використання сучасних супутникових знімків допомогли вирішити одне із головних питань даного дослідження - нанесення на карту міста територій 3 антропогенними ландшафтами. В ході польових досліджень були проведені спостереження за низкою промислових об'єктів: кар'єр та музей ПАТ «Південний гірничо-збагачувальний комбінат», Бурщицький відвал, відвал кар’єру гірничого департаменту ПАТ «АрселорМіттал Кривий Ріг», провалля шахт ім. Орджонікідзе та Тернівської, законсервована шахта ім. Шильмана, затоплені кар’єри: № 2-біс гірничого департаменту ПАТ
«АрселорМіттал Кривий Ріг», Карачунівський гранітний, ЦГЗКа, Ганнівський. Такі спостереження дали змогу зрозуміти закономірності організації та особливості просторового розвитку промислового комплексу міста.

Важливим у дослідженні методом був системний аналіз усіх економічних та екологічних аспектів промислового комплексу міста, як взаємопов'язаних систем чинників впливу на територію та екосистему в цілому. Порівняльний аналіз у даному дослідженні використано для співставлення взаємодії природних та антропогенних факторів впливу на геопросторові зміни території міста. Важливим для проведення дослідження є принцип комплексності досліджень, що дозволяє розробити рекомендації з дотриманням вимоги «не погіршення екологічної ситуації», дослідити всю систему, виявити іiі проблеми та сформувати перспективи для подальших досліджень.

Математичні методи дають можливість у дослідженні провести розрахунки, прогнозування, узагальнення, висновків, які без математичної складової не можливо отримати. У дослідженні ці методи завдяки своїй об'єктивності дозволяють порівнювати між собою певні об’єкти, виділяти головне серед великої кількості інформації та оцінити участь кожного фактору в загальній сумі впливів.

Метод літературних джерел було використано в процесі збору довідникового та історичного матеріалу. Статистичний метод $\epsilon$ основним у процесі обробки статистичних матеріалів різних інформаційних ресурсів міста Кривий Ріг та промислових підприємств. Він дозволив звести всі дані про сучасний стан промислового комплексу міста та всі зміни в процесі розвитку.

\section{Результати дослідження}

Початок промислового освоєння залізних руд у 1880 році був пов'язаний із організацією «Акціонерне Товариство Криворізьких залізних руд». Експлуатаційні роботи розпочаті у 1881 р. на руднику «Саксаганський». У тому ж році почалося будівництво Катерининськоїзалізниці, яка сполучила місто 3 промисловими районами Придніпров'я $\mathrm{i}$ Донбасу. Вона зіграла величезну роль у прискоренні розвитку промисловості регіону.

Наприкінці XIX ст. надзвичайно інтенсивно освоюється територія навколо тогочасного міста. Один за одним відкриваються рудники, біля котрих зводяться селища для робітників. У 1897 р. Кривбас виходить на перше місце по видобутку руди в Російській імперії, випередивши Уральський басейн. Перша шахта в басейні почала діяти в 1886 р. 3 тих пір 3 наростаючими темпами продовжувався підземний видобуток залізної руди. У 1890 р. на Криворіжжі діяло вже 79 рудників, а до кінця ХІХ сторіччя 266 промислових підприємств.

16 червня 1931 року голова ВСНХ СРСР Григорій Орджонікідзе підписує наказ про будівництво Криворізького металургійного заводу. 4 серпня 1934 року була запущена перша доменна піч. Цей день вважається днем народження заводу «Криворіжсталь». Невдовзі у 1936 р. закінчено будівництво Криворізького коксохімічного заводу.

У повоєнний час відбувається бурхливий розвиток промислового комплексу: збудовано в $1952 \mathrm{p}$. 
Криворізький цементний завод; у 1955 р. запрацювала перша черга Південного гірничо-збагачувального комбінату; 1959 р. введена в експлуатацію фабрика № 1 Новокриворізького гірничо-збагачувального комбінату; 1961 p. було збудовано першу чергу Центрального гірничо-збагачувального комбінату; 1962 р. здійснено пуск доменної печі №7 (ДП-7), оснащеної електронно-обчислювальною технікою, промисловим телебаченням; 1963-го відбувся пуск першої черги Північного ГЗК.

У 1965 році в місті діяло 573 підприємства. Впродовж 1960-1985 років промисловий потенціал міста продовжував зростати: 1966 р. на базі Інгулецького родовища залізистих кварцитів був створений Інгулецький гірничо-збагачувальний комбінат; 1969 року відкрито вагоноремонтне депо; 1970 року запущено унікальний комплекс шахти «Артем-2»; після запуску доменної печі -8 доменний цех Криворізького металургійного заводу став найбільшим у Європі; 1974 року відбувся пуск найбільшої у світі Доменної печі-9; 1975 року збудовано завод «Ремгормаш».

Наприкінці 1960-х років чисельність населення міста перевищила 500 тис. осіб. Об'єднанню робітничих селищ в складі Кривого Рогу сприяло завершення будівництва у 1958 р. 100-кілометрової асфальтної магістралі, що з'єднала місто з північними i південними рудниками та селищами біля них. Також місто Інгулець ввійшло до складу Кривого Рогу після 1963 р., в 1969 р. - Терни.

Як стає зрозуміло 3 історичного екскурсу, місто зазнало бурхливого розвитку із зростанням гірничо-видобувної промисловості у ХX столітті. Сучасний Кривий Ріг - це велике індустріальне місто, центр Криворізького залізорудного басейну найважливішої сировинної бази металургії України (Ostroushko, 2020).

Криворізький

індустріальний

регіон відіграє провідну роль в економіці України та $\epsilon$ основною сировинною базою для розвитку чорної металургії, має стратегічне значення для економічної незалежності та безпеки держави. У загальному внутрішньому валовому продукті України частка Кривого Рогу складає 9\%, національного експорту - 8\%, загального обсягу промислового виробництва, Дніпропетровської області - 42,3\% (Kryvyi Rih Investor's Guide, 2021).

Щороку підприємствами 3 видобутку та збагачення металевих руд випускається понад 70 млн т руди й залізорудних концентратів. На підприємствах металургії та оброблення металу щорічно виробляється більше 6,0 млн т сталі також більше 5 млн т чавуну та 5,5 млн т прокату.

У Криворізькому басейні розташовано 8 iз 11 підприємств України 3 видобутку та переробки залізорудної сировини, а також підприємства 3 обслуговування основного виробництва. Тому головною містоутворюючою галуззю, яка стійко визначає профіль міста в територіальному розподілі праці, є чорна металургія.

Криворізький залізорудний басейн - один 3 найстаріших і найбільших басейнів нашої держави. Тут видобувається понад $80 \%$ залізорудної сировини i виробляється 20\% металу України. Залізорудні родовища Кривбасу є комплексними за своїм складом, кожне 3 них складено двома-трьома типами залізних руд і супутніми нерудними корисними копалинами.
Питома вага гірничо-металургійного комплексу становить $86 \%$ загальних обсягів промислового виробництва в місті.

У Кривому Розі розташовано один із найбільших у світі металургійних комбінатів - «АрселорМіттал Кривий Ріг», чотири гірничозбагачувальних комбінати - Північний, Південний, Центральний, Інгулецький, гірничий департамент ПАТ «АрселорМіттал Кривий Ріг» 3 десятьма кар'єрами глибиною понад 300 м для відкритого способу відпрацювання, три рудоремонтні заводи та інші.

Переважна продукція, що виробляється цими підприємствами: залізна руда, концентрат, агломерат, котуни, чавун, сталь, готовий прокат. Єдиний у країні Криворізький суриковий завод виробляє залізний сурик, який має попит в Україні та за їі межами. Також у місті працюють Криворізький завод гірничого обладнання та Кривбасвибухпром (Kryvyi Rih Investor's Guide, 2021) (див. рис.1).

Місто отримало поштовх для розвитку не тільки через ресурсний потенціал, а і через вигідне географічне положення. Оскільки воно знаходиться в самому центрі України та має приблизно однакову відстань до всіх економічно найважливіших регіонів країни. Це дозволяє 3 порівняно невеликими витратами доставляти прокат на підприємства Донбасу та вже готову продукцію у порти Причорномор'я. Що дає змогу скоротити витрати на логістику у доставці промислових товарів до кінцевого споживача. Тому місто одним із перших у Російській імперії отримало залізничне сполучення і на сьогодні має одну 3 найбільш розгалужених мереж як пасажирської так і промислової залізничної інфраструктури в Україні. В місті розташована Криворізька дирекція залізничних перевезень «Укрзалізниці», яка обслуговує п'ять напрямів та щорічно забезпечує до $17 \%$ загальнодержавного обсягу всіх залізничних вантажоперевезень. Загалом добові обсяги вантажоперевезень становлять близько 200 тисяч тонн.

Підприємства міста мають значний вплив на економіку України. Так «АрселорМіттал Кривий Ріг» $\epsilon$ найбільшим експортером, 85\% готової продукції йде за кордон. На підприємстві працює більше 20 тис. робітників за даними 2019 року. Південний гірничо-збагачувальний комбінат в середньому видобуває 34 млн т гірничої маси руди на рік та має один 3 найбільших промисловий кар'єрів держави та Європи, (нині популярний наймасштабніший об'єкт індустріального туризму України), на підприємстві працює 6394 робітники. Новокриворізький гірничозбагачувальний комбінат увійшов до складу ПАТ «АрселорМіттал Кривий Ріг» (як гірничий департамент) та продовжує розробку родовища відкритим способом, видобуваючи в середньому 15,2 млн т руди на рік. На Центральному гірничозбагачувальному комбінаті видобуток ведеться відкритим способом та шахтним, всього на підприємстві працюють 4643 робітників. Північний гірничо-збагачувальний комбінат $є$ найбільшим гірничодобувним підприємством Європи 3 закінченим циклом підготовки доменної сировини - залізорудного концентрату та обкотишів (котунів) де родовища відробляються відкритим способом та працюють 5965 робітників. Інгулецький гірничозбагачувальний комбінат дає 70 млн т рудної 
маси щорічно та виробляє 14 млн т залізорудного концентрату, також на підприємстві працює 4931 робітник. ПрАТ «Кривий Ріг Цемент» - лідер в центральному i східному регіонах України 3 виробництва цементу, бетону і наповнювачів для будівельної сфери, спеціалізується на виробництві шлакових типів цементу та використовує шлаки та інші відходи металургійної індустрії Криворізького регіону. ПАТ «Суха Балка» - є підприємством, що спеціалізується на видобутку залізної руди підзем- ним способом, запаси яких розвідані до глибини 2060 м в полі шахти «Ювілейна» і до глибини 1500 м в полі шахти ім. Фрунзе (обидві шахти у своєму складі мають підземні бункерно-дробильні комплекси та наземні дробильно-сортувальні фабрики), на підприємстві працює 3000 робітників (Kryvyi Rih Investor's Guide, 2021).

Оскільки Криворізький регіон відзначається своєю промисловою складовою, то стає очевидним, що гірнича діяльність не могла проходити безслідно

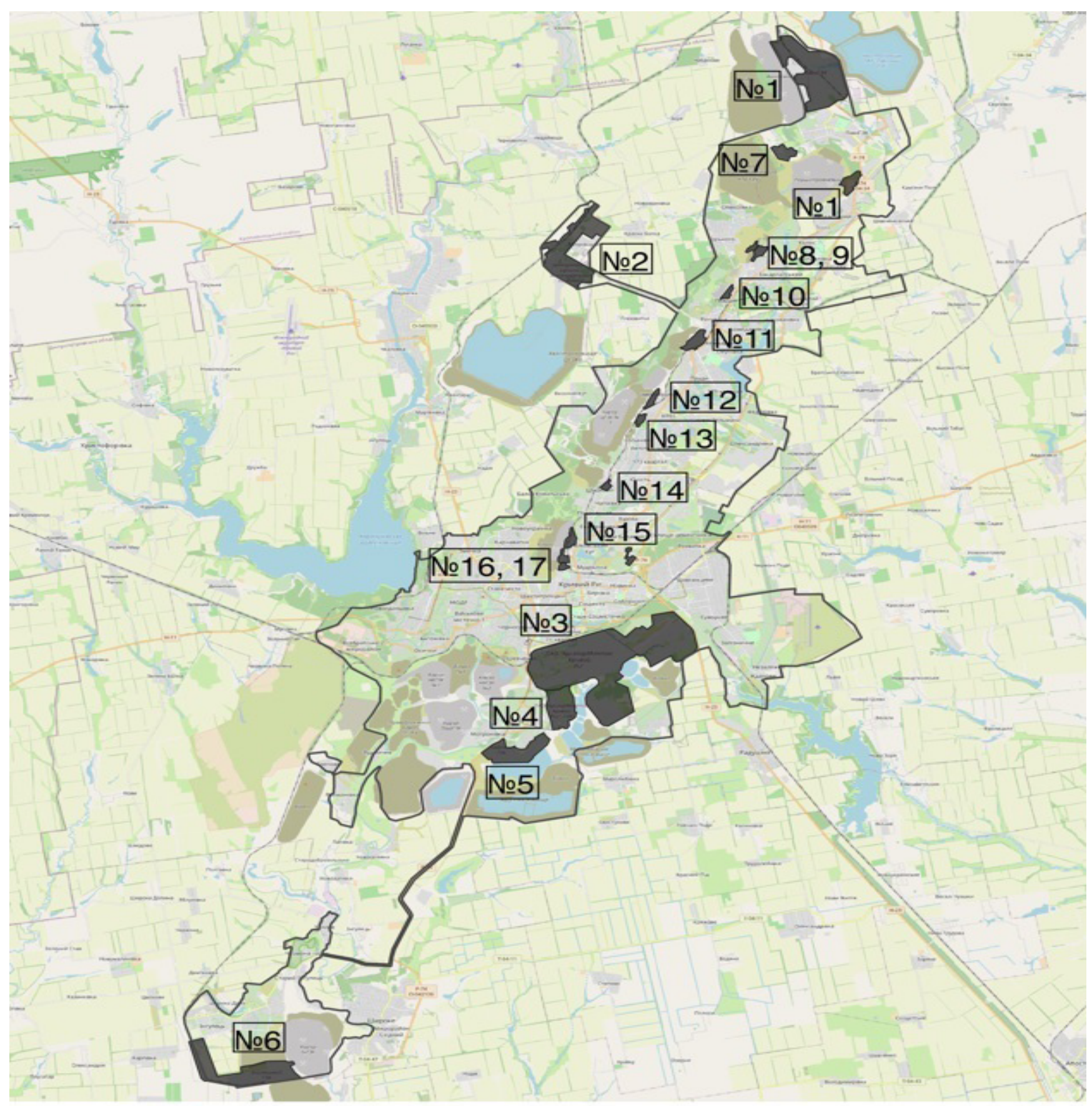

1ПрАТ "Північний ГЗК": 2)ПАТ 'Центральний ГЗК": 3)"Арселор Міттал Кривий Ріг": ДП-9: ПАТ Криворізький суриковий завод: ПрАТ "Кривий Ріг Цемент"; Криворізький коксохімічний завод: 4)ВАТ "Новокриворізький ГЗК"; 5)ВАТ "Південний ГЗК"; 6)ПАТ "Інгулецький ГЗК"; 7)Рудоуправління Першотравневе (шахта "Першотравнева"); 8)ПАТ ЦГЗК шахта імені Орджонікідзе: 9)ВАТ КЗРК шахта "Тернівська"; 10)ВАТ КЗРК шахта "Твардійська": 11)ПАТ "Свраз Суха балка" шахта "Ювілейна"; 12)ПАТ "Євраз Суха балка" шахта ім. М.В.Фрунзе; 13)ВАТ КЗРК шахта "Октябрьська"; 14)ВАТ КЗРК шахта Родіна"; 15)ПАТ "Арселор Міттал Кривий Ріг" 이 ім.Артема; 16)"Кривбасруда" шахта "Саксагань"; 17) ПАТ ЦГЗК шахта "Гігант-глибока". 
протягом майже 150-ти років. Через розвиток видобутку залізних руд відкритим, тобто кар'єрним способом, на сьогодні ми можемо бачити наслідки цієї діяльності у вигляді кар'єрів, відвалів та шламосховищ, які займають величезні площі які можна порівняти 3 площами багатьох великих міст України. Таким чином виникають антропогенні ландшафти, як наслідки розкривних і видобувних гірничих робіт, складування порожньої гірської породи та відходів переробки і збагачення корисних

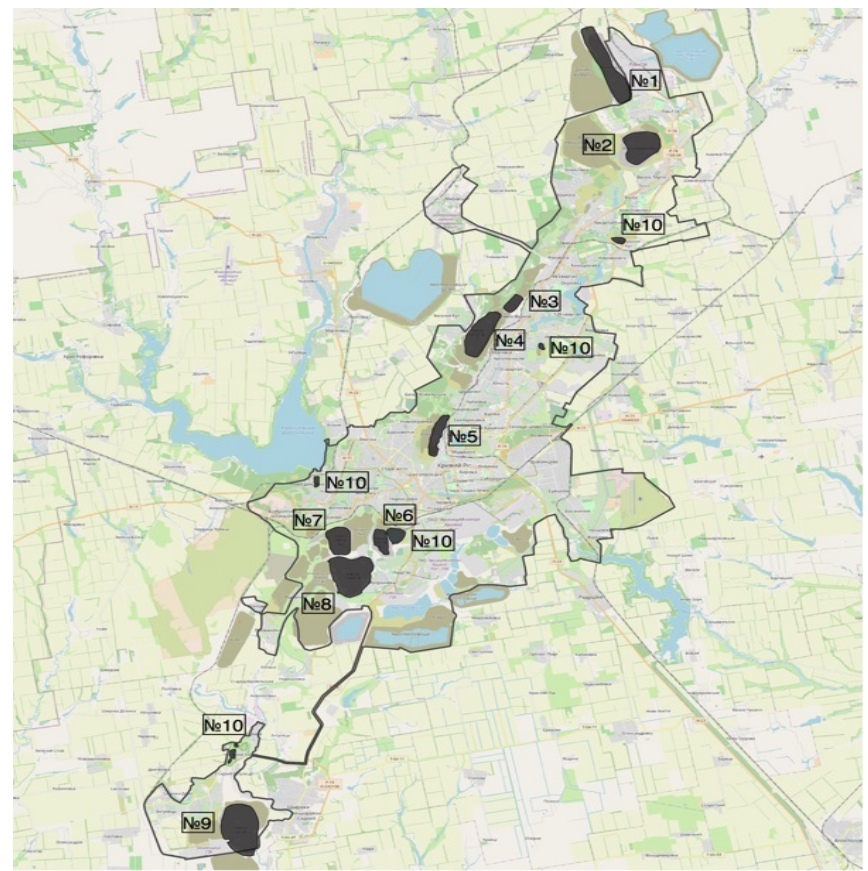

1)Ганнівський кар'єр; 2)Першотравневий кар'єр; 3)Кар'єр ЦГЗК 4)Глеюватський кар'єр; 5)Кар'єри Південний та Північний 6)Кар'єр №2 НКГЗК: 7)Кар'єр №3 НКГЗК: 8)Кар'єр ПівдГЗК: 9)Інгулецький кар'єр; 10)Затоплені гранічтні кар'єри.

Рис. 2. Картосхема кар'єрів

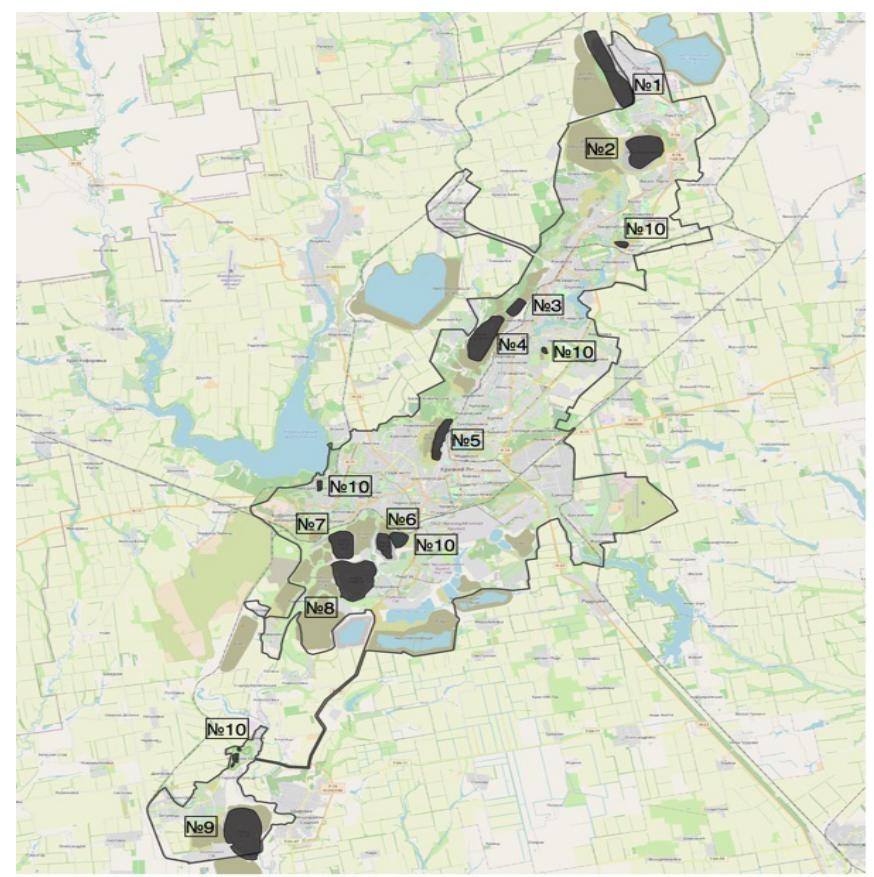

1)Ганнівський кар'єр; 2)Першотравневий кар'єр; 3)Кар'єр ЦГЗК; 4)Глеюватський кар'єр; 5)Кар'єри Південний та Північний 6)Кар’єр №2 НКГЗК; 7)Кар’ер №3 НКГЗК; 8)Кар’єр ПівдГЗК 9) Інгулецький кар'єр; 10)Затоплені гранічтні кар'єри. копалин, утворення підземних порожнин в шахтах 3 наступним їх погашенням та зрушенням підроблених блоків земної кори (Tiutiunnyk, 1991). Через це постає значна екологічна та техногенна проблема на Криворіжжі, оскільки на сьогодні в Україні не реалізована технологія 3 переробки відпрацьованих шламових та відвальних порід. Тому єдиним способом наразі залишається накопичувати ці породи у вже існуючих шламосховищах, відвалах та займати ними все нові і нові території.

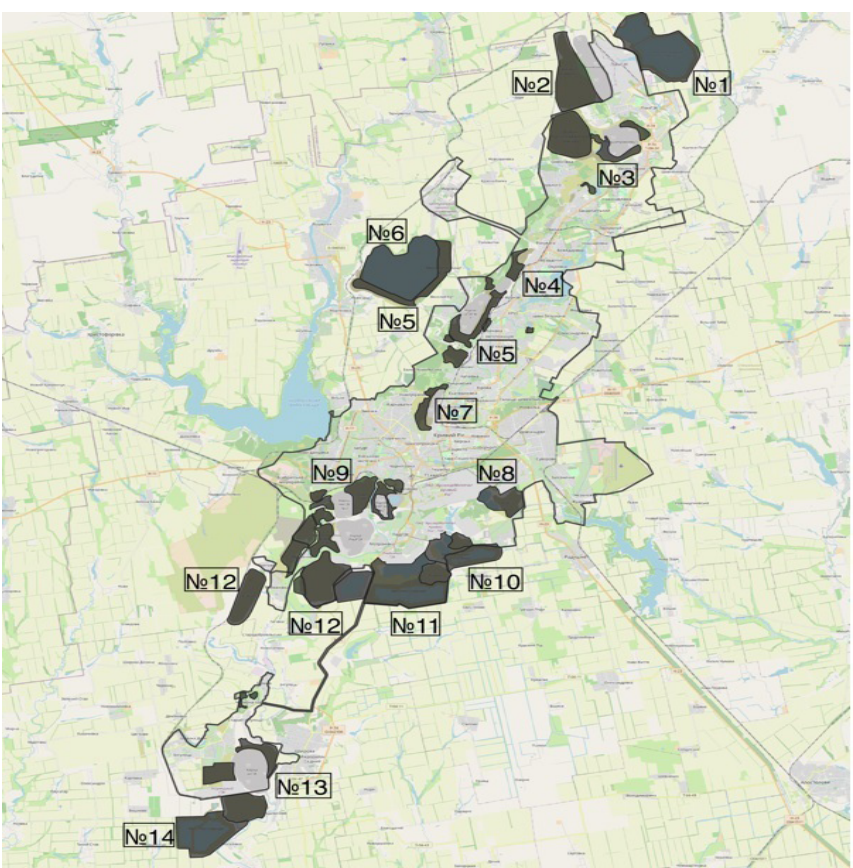

1)Шламосховище ПівнГзК 2)Відвал Ганнівського кар'еру 3)Відвали Першотравневого кар'еру 4)Відвал кар'еру ЦГЗК 5)Відвали Глеюватського кар'еру 6)Шламосховище ЦГзК 7)Відва НКГЗК 10)Шламостовище НКГЗК 11Шламосховище ПівдГЗК 12)Відвали кар'еру ПівгГЗК 13)Відвали кареру ІнГЗК 14)Шламосховище ІнГЗК.

Рис. 3. Картосхема відвальних ландшафтів

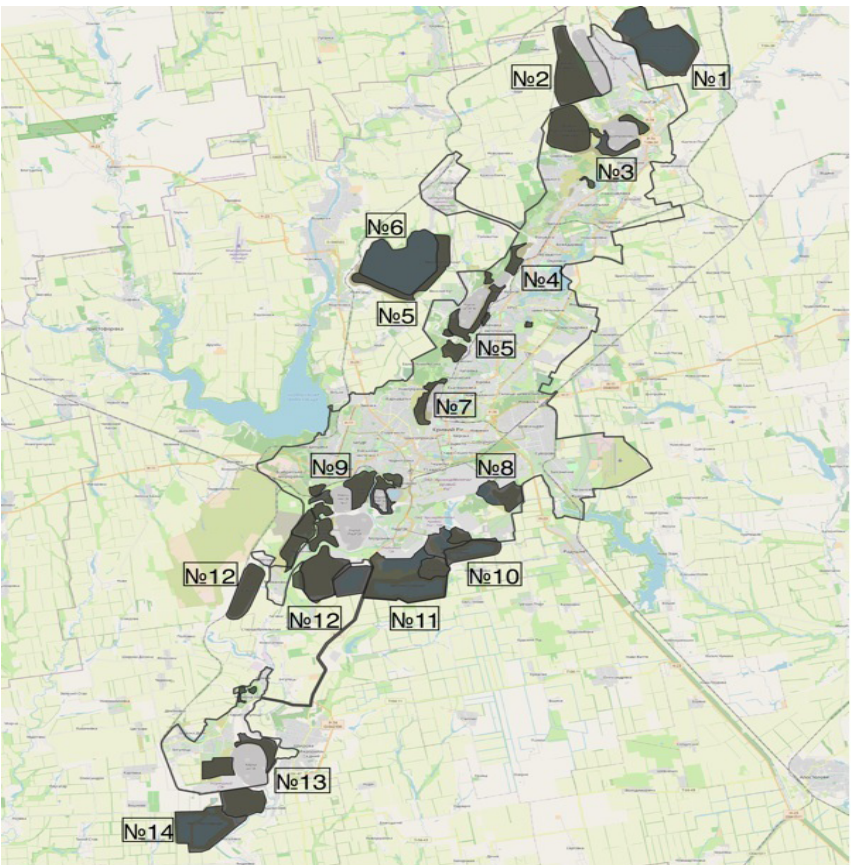

1)Шламосховище ПівнГзК 2)Відвал Ганнівського кар'еру 3)Відвали Першотравневого кар'єру 4)Відвал кар'еру ЦГЗК 5)Відвали Глеюватського кар'еру 6)Шламосховище ЦГЗК 7)Відва НКГЗК 10)Шламосховище НКГЗК 11раламосховище ПівдГЗК 12)Відвали кар'еру ПівдГЗК 13)Відвали кар'еру ІнГЗК 14)Шламосховище ІнГЗК. 
Кар'єри являють собою негативну форму рельєфу техногенного походження, в межах якої відкритим способом відбувається видобуток корисних копалин. На території Криворіжжя налічують всього 54 кар'єри (працюючі та виведені з експлуатації, 3 повторною експлуатацією): 41 залізорудний, 4 гранітні, 6 піщаних, 3 глиняні. Головною умовою закладення кар'єрів є неглибоке залягання родовища корисних копалин і перекриття незначною товщею наносів осадових порід (див. рис. 2).

Відвальні гірничопромислові ландшафти формуються на основі таких техногенних утворень як відвал. Відвали $є$ однією 3 основних форм антропогенного рельєфу, який утворюється внаслідок складування розкривних порід на земній поверхні та складування на земній поверхні побічних продуктів збагачення корисних копалин - шламів в процесі розробки кар'єрів. Відвали формуються з «пустих» та «бідних» порід які не підлягають збагаченню. В свою чергу шлам виникає як побічний продукт переробки руди після відбору магнітної фракції на магнітних сепараторах який відбувається під час збагачення руди на гірничо-збагачувальних комбінатах. Після цієї процедури шлам перекачується до шламосховищ, де і зберігається. Відвали поділяються за типами на шламосховища (гідровідвали), пухкі (суглинисті, супіщані), скельні та змішані. Всього на території Криворіжжя налічується 104 відвали від низьких (висотою до 20 метрів) до над високих (майже всі шламосховища 3 висотою 110-130 м). Також відвали відрізняються за площею від дуже малих (до 50 га) до великих, де площа становить понад 300 га (площа найбільшого шламосховища Північного ГЗК - 1840 га або 18,4 км²) (див. рис. 3).

Після кар'єрів і відвалів - провальні ландшафти являють третю групу гірничопромислових антропогенних ландшафтів, виникнення яких пов'язане $з$ підземним видобутком залізних руд та зрушенням прилягаючих блоків корінних гірських порід. Провальні ландшафти на території Криворіжжя є двох типів: зони зрушення та провальні зони (зони утворення лійок, котловин). Всього налічують 26 таких зон (див. рис. 4).

На сьогоднішній день загальна площа гірничопромислових ландшафтів Кривбасу становить

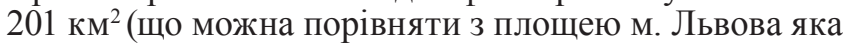

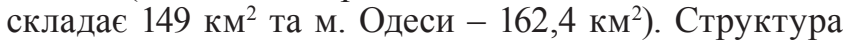
гірничопромислових ландшафтів міста виглядає наступним чином: площа кар'єрів становить понад 42 км²; площа відвалів - 70 км²; площа шламосховищ - 55

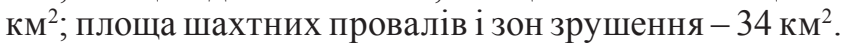
Наведені цифри постійно змінюються, через невпинне продовження та розростання гірничодобувних робіт та відвалоутворення (Kazakov, 2000; Kazakov \& Herasymchuk, 2008) (див. рис. 5).

Для розуміння всього комплексу геопросторових змін території міста та регіону важливим є питання географічних особливостей Криворіжжя. Територія розташована у степовій зоні та не має великих природних джерел водопостачання. А розвиток промислового комплексу міста напряму був пов'язаний зі створенням необхідних запасів якісної прісної води. Це завдання було вирішене розбудовою низки водосховищ на існуючий річковій мережі та проведенням каналу Дніпро - Кривий Ріг довжиною в 41,3 км. Масштабне будівництво дало змогу забезпечити постачання величезних обсягів води для потреб промисловості та населення міста.

Водопостачання міста і Криворізького регіону здійснюється 3 двох основних джерел: Карачунівського водосховища та Південного водосховища. Всього біля міста знаходиться 5 водосховищ, які виконують різні функції:

- Карачунівське водосховище (площа сягає

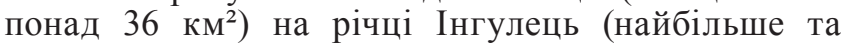
найстаріше - 90 років) використовується як

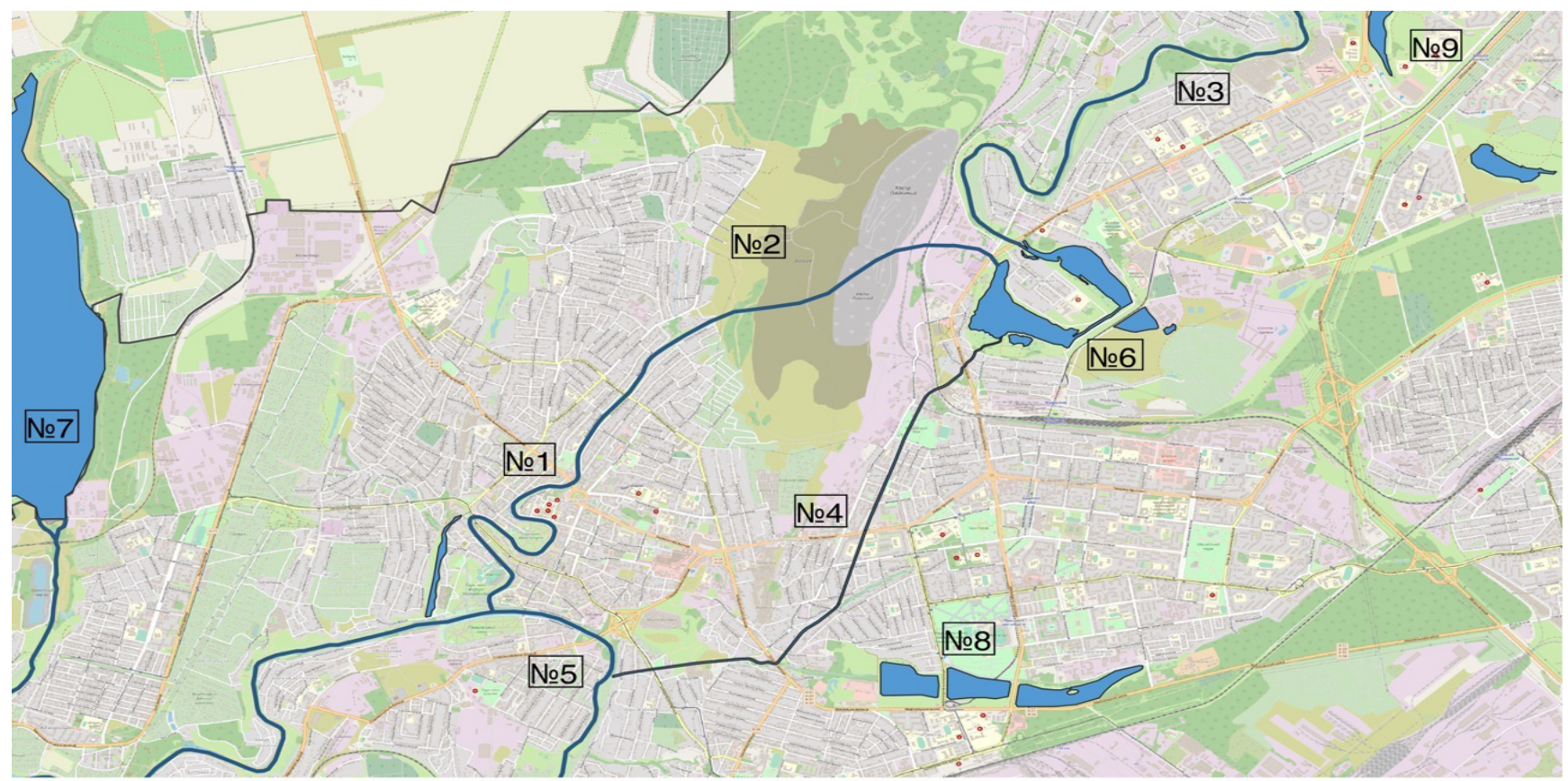

1)Старе русло р.Саксагань; 2)Траекторія р.Саксагань до закладення Південного та Північного кар`єрів; 3)р.Саксагань; 4)Саксаганський дериваційний тунель; 5)р.Інгулець; 6)Саксаганське водосховище; 7)Карачунівське водосховище; 8)Ставки-відстійники "Арселор Міттал Крвий Ріг"; 9)Ставки мікрорайонів "Сонячний" та "Гірницький". 
джерело водозабору, зона відпочинку, для рибного господарства, зрошення земель та регулювання рівня паводкових вод. У 1930 роцізакладено узв'язку 3 будівництвом Криворізького металургійного заводу (тепер - «АрселорМіттал Кривий Ріг»).

- Південне водосховище створене штучно у балках Тарановій і Чебанці (басейн річки Кам'янки). Збудоване у 1961 р. для накопичення дніпровської води, яка подається до нього каналом Дніпро-Кривий Ріг і призначена для питних та побутових цілей, зрошення сільськогосподарських угідь.

- Іскрівське водосховище споруджено 1958 року. Довжина 35 км, ширина до 1,7 км. Водосховище споруджене для технічного водопостачання Криворізького басейну та міста Жовтих Вод, а також для зрошування.

Кресівське водосховище створене на річці Саксагань на початку XX століття для гідроелектростанції. Вода може використовуватися тільки в технічних цілях.

Макортовське водосховище на річці Саксагань в 25 км від м. Жовті Води, створене у 1958 р. Водосховище являється першим 3 каскадів саксаганських водосховищ та акумулює стік Саксагані. Вода використовується для промислового водозабеспечення Криворізького залізорудного басейна, зрошення сільськогосподарських земель (Ostroushko, 2020) (див. рис. 6).

Саксаганський дериваційний тунель споруджено у 1957 р., одночасно з Саксаганським водосховищем. Будівництво тунелю було зумовлене наявністю багатих залізних руд в річищі Саксагані, по відведенню річки було розпочато видобуток залізної руди у новозакладеному кар'єрі «Південний», розташовані в шахтному полі рудника ім. Кірова.

Тунель, завдовжки 5,3 км, на глибинах від денної поверхні 24-65 м, від Саксаганського водосховища до вихідного порталу на річці Інгулець. Вихідний портал - тобто сьогоденне гирло річки Саксагань, знаходиться на 1,5 км нижче за течією річки Інгулець, ніж історичне гирло.

На жаль, промисловий розвиток регіону окрім економічно-соціальних зисків та геопросторових змін території призвів до серйозних екологічних наслідків. Кривий Ріг є одним 3 найбільш небезпечних в екологічному плані міст України. Підприємства гірничодобувної та переробної промисловості, яким місто може завдячувати своєму розвитку, є i його найбільшою проблемою. Обсяг виробленої продукції на підприємствах комплексу досягає 33\% від загального обсягу виробництва в Україні, а викиди забруднюючих речовин в атмосферне повітря підприємствами комплексу за даними Дніпропетровської обласної ради становлять понад 260 тис т,а за неофіційними даними, щорічно складають понад 1,5 млн т, або майже $32 \%$ від загальних викидів в країні. Із цих даних стає зрозуміло, яке надзвичайне екологічне навантаження отримує 600-тисячне населення промислового міста та навколишнє середовище.

Найбільшого негативного впливу від діяльності підприємств Криворіжжя зазнає атмосферне повітря. Основними забруднюючими речовинами $є$ оксид вуглецю (73\%), пил (15\%), діоксид сірки (3\%) та інші шкідливі речовини (сірководень, аміак, фенол, формальдегід та інші). Хоча офіційна статистика наголошує на щорічному зменшенні викидів в атмосферу та покращення технологій очищення на підприємствах регіону, насправді суспільні активісти та незалежні екологи фіксують неодноразові несанкціоновані викиди шкідливих речовин в атмосферу та значно більші показники викидів (Chasova \& Ivchuk, 2012).

В липні 2019 року уряд створив «Офіс контролю викидів в атмосферу» в Кривому Розі. Головним завданням цієї інспекції $\epsilon$ контроль викидів підприємств - забруднювачів. Адже мережа пунктів контролю знаходиться в системі самих підприємств, тому реальний стан викидів та навіть доступ незалежних екологів на підприємства надзвичайно ускладнений.

Низький рівень ефективності використання надр і сировини при значних обсягах його видобутку призвів до великих втрат корисних копалин в надрах i накопичення великої кількості відходів виробництва у вигляді відвалів та шламів. Однією 3 проблем $\epsilon$ забруднення грунтів в результаті діяльності промислових підприємств. Забруднюючі речовини потрапляють в атмосферне повітря, а потім осідають на грунті та вимиваються опадами в радіусі до 5 км від стаціонарного джерела викидів.

Одним з об'єктів навколишнього середовища, найбільш важливим для людини і в той же час найбільш схильних до впливу важких металів, $є$ природні води. Їх забруднення важкими металами відбувається через скиди недостатньо очищеної води підприємствами гірничодобувної, металургійної та металообробної промисловості безпосередньо в річки регіону. Приблизно половина міських стічних вод скидаються у водні об'єкти недостатньо очищеними, 3 них близько $15 \%$ - взагалі без очистки. Без будьякого очищення скидаються до $70 \%$ виробничих стічних вод.

Серед найбільш забруднених річок слід зазначити p. Інгулець. Також незворотного негативного впливу зазнала річка Саксагань. Природний режим річки сильно змінений регулюючим впливом дамб, скиданням шахтних i промислових вод, а також відбором води на технічні потреби. Також переведення значної ділянки ріки у дериваційний канал призвело до заболочування старої частини русла. Намагання підживлювати старе русло штучно трубопроводом iз Карачунівського водосховища не дало бажаного результату. Тому велика ділянка ріки на території міста фактично поступово заболочується.

Значна концентрація потенційно небезпечних об'єктів на території міста (шахти, кар'єри, відвали, шламосховища, відпрацьовані пустоти, тощо), які за умови припинення відкачки підземних вод або переповнення накопичувачів неминуче стануть джерелом розвитку надзвичайних ситуацій та техногенних катастроф. Відсутність реальної альтернативи повного використання або утилізації надлишків зворотних вод диктує необхідність у щорічному вживанні заходів зі скиду надлишків зворотних вод гірничорудних підприємств Кривбасу.

Великою проблемою міст України $\epsilon$ захоронення виробничих та побутових відходів. Складність проблеми пропорційна чисельності населення та промисловому потенціалу міста. У металургії i теплоенергетиці для зберігання відходів використовується до $40 \%$ території 
підприємства. В результаті чого формуються унікальні антропогенні ландшафти в безпосередній близькості до проживання людей. Вони обумовлені наявністю відходів видобувної промисловості які представлені у вигляді відвалів, шламосховищ, териконів та звалищ, що формують зони техногенного опустелювання, площа яких до кінця XX ст. склала близько 8\% від загальної території України. Навіть за даними офіційної статистики викиди шкідливих речовин складають понад 395 тис. т - 590 кг на особу. Але незалежні експерти говорять про перевищення цих даних у декілька разів. Також на підприємствах регіону накопичилося майже 9 млрд т промислових відходів, що спричиняє засмічення величезних територій родючих земель.

У процесі виробничої діяльності підприємств Кривого Рогу щорічно утворюється більше 169 млн м ${ }^{3}$ промислових відходів, які вивозяться у відвали та шламосховища, де вже зберігається понад 2,5 млрд м $^{3}$ відходів збагачення; вони займають площу близько 16 тис. га. Це означає, що величезні території родючих земель втрачені назавжди, і площа цих об'єктів 3 кожним роком буде збільшуватись. Потрібно зазначити, що ці об'єкти також мають негативний вплив на навколишне середовище оскільки вони запилюють величезні території сільськогосподарських угідь, житлових територій (Chasova \& Ivchuk, 2012).

Основні підприємства-забруднювачі знаходяться в безпосередній близькості до житлових масивів, оскільки історично міська житлова забудова формувалася для потреб кожного підприємства. Видобуток руди в надрах, відкачка підземних вод, величезна кількість штучних відкладень створених людиною - викликають зміни в геологічній структурі чим викликають посилення техногенної кризи.

Міською екологічною програмою передбачено виконання промисловими підприємства модернізації існуючих виробничих потужностей та пилогазоочисних установок, будівництво нових ефективних систем пило- та газовловлення, а також комплексу заходів 3 пилопригнічення на відвалах, шламосховищах, складах продукції, промислових майданчиках, автошляхах, вулицях житлових масивів в зоні впливу виробничої діяльності у тому числі з використанням зв'язуючих речовин, а також співпраця зі спеціалізованими науковими організаціями 3 питань розробки, розгляду та впровадження нових технологій з пилопригнічення, в тому числі «зелених технологій». Але всі передбачені програмою заходи потребують постійного державного контролю (Kryvyi Rih Ecologic Passport, 2017).

\section{Висновки}

Місто зазнало стрімкого економічного розвитку в XX ст. 3 містечка в 20 тис. осіб воно виросло у велике місто, яке на початку незалежності досягало майже мільйона осіб. Промисловий розвиток став поштовхом до розвитку житлового будівництва та об'єднання багатьох містечок Кривбасу у велике місто, яке є найдовшим в Україні та Європі.

У радянський час збудований металургійний завод «Криворіжсталь» (нині ПАТ «АрселорМіттал Кривий Ріг») та 5 гірничо-збагачувальних комбінатів, які стали найбільшими підприємствами гірничої та металургійної справи України. Це призвело до розвитку залізниці, авто- та авіа шляхів сполучення.

Що стало вирішальним чинником для стрімкого розвитку міста. На сьогоднішній день Кривий Ріг - це «металургійна столиця України», одне 3 найбільших міст та має величезні перспективи для розвитку та покращення рівня життя. У місті є один з найнижчих показників рівня безробіття.

Але водночас підприємства міста $\epsilon$ і одними 3 найбільших забруднювачів атмосферного повітря в Україні, які чинять негативний вплив на атмосферне повітря, річки та родючі грунти регіону. Через незадовільний стан компонентів природного середовища спричиняє захворюваність жителів Кривого Рогу на легеневі хвороби та рак є дуже високою.

Утворені в результаті видобутку та переробки залізної руди промислові ландшафти несуть потенційну техногенну небезпеку та потребують постійного пошуку рішень по їх рекультивації, консервації та утилізації відходів виробництва.

Хоч за останні десятиліття почали застосовувати системи пило- та газовловлення, а темпи видобутку та переробки впали, тим самим зменшивши вплив на навколишне середовище, екологічна ситуація в місті є дуже складною і потребує постійного контролю з боку державних екологічних інспекцій та громадськості.

\section{References:}

Chasova, E., \& Ivchuk, V. (2012). Ecological problems of Kryvbas: current state and prospects. Bulletin of Kryvyi Rih National University, 30, 215-219. [In Russian]. [Часова Э. В., Ивчук В. В. Экологические проблемы Кривбасса - состояние и перспективы // Вісник Криворізького національного університету. 2012. Вип. 30. C. 215-219.]

Kryvyi Rih Ecological Passport (2017). Режим доступу: https://kr.gov.ua/ua/news/pg/190117418982655 n/ [In Ukrainian]. [Екологічний паспорт міста Кривого Рогу. 2017. Режим доступу: https://kr.gov.ua/ua/news/ pg/190117418982655_n/]

Kryvyi Rih Investors Guide (2021). Access mode: https://ig.krmisto.gov.ua/ua/citycard/econ.html.

Kazakov, V. (2000). Anthropogenic landscapes of Kryvbas. In Diversity of Landscape Complexes in Ukraine and Ways of Their Rational Use and Preservation: Methodological and Applied Aspects. Collection of conference papers (pp. 41-46). Kyiv. [In Ukrainian]. Казаков В. Л. Антропогенні ландшафти Кривбасу // Різноманіття ландшафтних комплексів України та шляхи їх раціонального використання і збереження: методологічні і прикладні аспекти. 3б. наук. праць наук. конф. Київ, 2000. С. 41-46. [Казаков В. Л. Антропогенні ландшафти Кривбасу // Різноманіття ландшафтних комплексів України та шляхи їх раціонального використання i збереження: методологічні і прикладні аспекти. Зб. наук. праць наук. конф. Київ, 2000. С. 41-46.]

Kazakov, V., \& Herasymchuk O. (2008). Underground mining landscapes of Kryvbas as a subject of anthropogenic landscape science: problem statement. Heohrafichni Doslidzhennia Kryvbasu, 3, 6-13. [In Ukrainian]. [Казаков В. Л., 
Герасимчук О. О. Підземні гірничопромислові ландшафти шахт Кривбасу як об’єкт вивчення антропогенного ландшафтознавства: постановка проблеми // Географічні дослідження Кривбасу. Вип. 3. Кривий Ріг: КДПУ, 2008. C. 6-13.]

Ostroushko, M. (2020). On the water supply and sewerage system hystory in Kryvyi Rih. In XVI Vseukrajinski Naukovi Talijivski Chytannia (p. 99). Kharkiv. [In Ukrainian]. [Остроушко М. В. До історії формування системи водопостачання і водовідведення в місті Кривий Ріг // XVI Всеукраїнські наукові Таліївські читання. Харків, 2020. C. 99.]

Ostroushko, M. (2020). Surface waters as a factor geospace formation in Kryvyi Rih. In Strategy of Urban Development: Youth and Future (Innovative Lift): materials of the international scientific and practical conference (p. 355). Kharkiv. [In Ukrainian]. [Остроушко М. В. Поверхневі води як чинник формування геопростору в м. Кривий Ріг // Стратегія розвитку міст: молодь і майбутнє (інноваційний ліфт): матеріали Міжнародної науково-практичної конференції. Харків, 2020. С. 355.]

Smetana, M., \& Provozhenko, T. (1997). To the classification of anthropogenic landscapes of Kryvbas. In Environmental Protection: Ecological, Medical, Educational Aspects. Conference Papers (pp. 3-5). Kryvyi Rih. [In Ukrainian]. [Сметана М. Г., Провоженко Т. А. До класифікації антропогенних ландшафтів Кривбасу // Охорона довкілля: екологічні, медичні, освітянські аспекти. Матер. 2-ї Всеукр. конф. Кривий Ріг, 1997. C. 3-5.]

Tiutiunnyk, Yu. (1991). Identification, structure and classification of landscapes of urbanized areas. Geography and Natural Resources, 3, 22-28. [In Russian]. [Тютюнник Ю. Г. Идентификация, структура и классификация ландшафтов урбанизированных территорий // География и природные ресурсы. 1991. № 3. С. 22-28.] 